Marquette University

e-Publications@Marquette

$1-1-2016$

\title{
The Relationship Between Marketing Ethics and Corporate Social Responsibility: Serving Stakeholders and the Common Good
}

Gene R. Laczniak

Marquette University, eugene.laczniak@marquette.edu

Patrick E. Murphy

University of Notre Dame

Published version. "The Relationship Between Marketing Ethics and Corporate Social Responsibility :Serving Stakeholders and the Common Good" in Handbook of Research on Marketing and Corporate Social Responsibility, edited by Ronald Paul Hill and Ryan Langan. Cheltenham, UK; Northampton, MA : Edward Elgar, 2016: 68-87. Publisher link. (C) 2016 Edward Elgar. Used with permission. 


\section{The relationship between marketing ethics and corporate social responsibility: serving stakeholders and the common good}

Gene R. Laczniak and Patrick E. Murphy

Marketing ethics (ME) and corporate social responsibility (CSR) are related concepts that often cause definitional confusion among academics attempting to analyze social issues in marketing. The same linguistic obstacles confound public policy makers when they suggest regulatory adjustments to market sectors, especially when they invoke descriptors couched in ethical or socially responsible phraseology. Academic researchers also regularly struggle with the ME and CSR terminology due, in part, to confusion deriving from the 'level of analysis' that is being addressed (manager's focus versus firm-centered orientation).

The purpose of this chapter is to explore the concepts of ME and CSR, establish their relative relationship and, in so doing, develop deeper insights about how these two constructs strategically connect. Thus, in the dialogue below, we hope to untangle these definitions and better position CSR in its historic, normative role as it complements traditional insights into marketing ethics. Another desired payoff is that this exercise will help scholars develop clearer perspectives about what moral obligations marketing practitioners normatively owe the stakeholders that they impact both financially and socially.

While our discussion of these complex terms will probably be found by some readers to be unsatisfactory because this is not a comprehensive literature review, we hope to take the analysis - rooted in the extant literature to be sure - to a fuller and more macro level than normally found in academic treatises about these concepts. We also intend to develop the theme that marketing ethics is not simply about managerial decisions and that CSR is not mainly about organizational policies. Instead, both concepts reinforce one another and are central to understanding the role of marketing in society, and in particular, to the development of the common good. Our view is that marketing ethics, when blended with CSR perspectives, represents a profound statement about the moral duties owed by all marketing practitioners to the broader society as it is affected by business operations. 


\section{CORE DEFINITIONS}

The seventeenth-century French intellectual and philosopher Voltaire often remarked, 'If you would speak with me, define your terms.' Thus, at the outset, it is helpful to define marketing ethics, its corollaries and CSR.

'Marketing ethics', a sub-discipline of business ethics, is the systematic study of moral standards as applied to marketing decisions, behaviors and institutions (Laczniak and Murphy 1993). Marketing ethics has two dimensions, positive and normative. Positive ethics describes what marketing managers actually do regarding ethical situations - for example, the number of annual ethical violations per industry code or the percentage of managers in a business sector who have completed formal ethics training programs. Most of the academic research about ME is 'positive' as it charts statistics or uncovers empirical regularities between variables of interest (Nill and Schibrowsky 2007; Schlegelmilch and Oberseder 2010). For example, positive ethics seeks to answer important questions such as: does the existence of an enforced company code of ethics lead to higher customer satisfaction? Or, is the presence of ethics training in a company correlated with fewer consumer complaints? Positive ethics is essential to the understanding of how marketing managers behave. However, positive ethics is incomplete without its linkage to normative ethics - that is, how marketing managers ought to behave professionally. Normative ethics specifies the target ideals according to which marketers should conform, stipulating a set of moral standards. Here is what we once observed about the symbiosis of positive marketing with normative ethics (Laczniak and Murphy 2006, p. 157):

Positive marketing ethics has developed a rich tradition represented by tests of the now classic Hunt-Vitell model (1986) demarcating how marketing managers actually make their ethical decisions. And, it is only in knowing how managers approach ethical problems that one can begin to assess the gap between current practices and the ideals of normative marketing ethics.

The above comment implies that there exists some ideal, which is the aspirational aspect of marketing ethics, and we label it 'ethical marketing'. Ethical marketing (EM) - the normative aspect of marketing ethics - involves practices that emphasize transparent, trustworthy and responsible organizational practices and actions that exhibit integrity as well as fairness to consumers and other stakeholders (Murphy et al. 2005). We have utilized this definition in executive training and, at its surface level, it has almost always received an approving reaction from practitioners. In other words, marketing managers perceive that this general 
definition of ethical marketing captures what practitioners imagine this concept to mean. However, reality is not so simple. At a deeper level, the definition of ethical marketing contains difficult-to-operationalize terms involving the nature of trust, integrity, transparency and fairness. Hence, when one addresses specific instances of questionable marketing practice, the straightforwardness of what constitutes ethical marketing disappears. For example, if a particular firm proclaims that it is all about maximizing profits and then always acts in precisely this way (in conformance with the law, of course), is that exhibiting integrity? Clearly, they are 'walking the talk'. If airline companies adjust their prices hourly depending on changing customer demand, is that fair? If a large bank brands its sub-prime lending operations under a different name and logo, but that relationship is publicly registered and discoverable, is that transparent? Questions such as these (we hope) show some of the complexity of establishing the true nature of ethical marketing.

Finally, corporate social responsibility (CSR) in marketing encompasses marketing's obligation to all its stakeholders to 'fairly' integrate stakeholder claims with the firm's moral and legal duties to its constituencies including society at large (adapted from Murphy et al. 2013). Consistent with marketing ethics, CSR also could be thought of as having positivé and normative dimensions because (for example) academic and survey research can describe what businesses 'responsibly' undertake versus what society thinks they ought to do. With that distinction on the record, CSR is an inherently normative concept since, as its name implies, certain societal obligations of marketing (and business) extend beyond basic economic and fiduciary duties. Why is this so? It is true because marketing is almost always played out in a social context and, therefore, marketing has societal effects for which there is discernible accountability and obligation.

We can hardly claim that our definition (above) is the indisputable articulation of CSR, but for reasons described below, we think it captures its essence. One recent study uncovered and commented on 37 different definitions of CSR (Dahlsrud 2008), a point to which we shall return. But for the moment, let us begin at the beginning.

Howard Bowen, thought by many to be 'the father of CSR', defined the social responsibilities of business thus: 'the obligations of businessmen to pursue those policies, to make those decisions or to follow those lines of action which are desirable in terms of the objectives and values of society' (Bowen 1953, p. 6). It is of particular interest and significance to note his distinct focus on the decisions made by company managers to contribute to social objectives in his CSR definition. This suggests that Bowen perceived CSR as having roots in the decisions made by individual managers - a theme of marketing ethics - rather than having its central 
focus only on the larger institutional policies and culture of a given firm, a view quite common today.

Archie B. Carroll, one of the most prolific commentators on CSR over the years, typically positioned his discussions of CSR as addressing the responsibilities of corporations to society that extend beyond those owed to stockholders and investors (Carroll 1979; 1999). Such supra-fiduciary responsibilities clearly imply the notion of other stakeholders - all those parties affecting or affected by the actions of the organizations (Freeman 1984). Within the numerous definitions of CSR, and further complicating our comprehension, are related constructs such as the citizenship of business, social and environmental impacts, the secondary economic benefits of exchange and, of course, the nature of stakeholder theory itself.

Matten and Moon (2008), in an analysis of the welter of numerous CSR definitions, suggest that a lack of a common definition is to be expected because (a) CSR is an umbrella term for many related ideas, and (b) CSR naturally evolves over time as societal values shift; thus CSR might be seen as inherently subjective across time. Nevertheless, when one examines our three featured definitions together-marketing ethics, ethical marketing and CSR - this much seems clear: (1) ME, EM and CSR are related and overlapping concepts; (2) ME and its corollary EM are somewhat more individual and managerial while CSR is slightly more collective and organizational; (3) ME, EM and CSR interact and co-influence to shape the artifacts of socially responsive corporate managers, policies, climate and culture; (4) when commentators discuss the level of marketing ethics embodied in a particular practice, company or industry sector, there are often implications for how CSR is being discharged and exercised. We elaborate on these points below.

\section{KEY LITERATURE: MARKETING ETHICS AND CSR}

The amount of commentary in the marketing literature that specifically explores the connection between marketing ethics and CSR is fairly thin. The most direct contribution in this vein is Robin and Reidenbach's (1987) Journal of Marketing article. These authors state that ethics 'requires that the organization or individual behave in accordance with the carefully thought-out rules of moral philosophy', while 'corporate social responsibility is related to the social contracts between business and society in which it operates' (p. 45). Exactly what distinction the authors were trying to underscore with this contrast is not precisely evident, although one might surmise that they see marketing ethics as more micro (functionspecific) while CSR comes into play when the system-wide impacts of 
business are called into question; hence CSR is both more macro and societal focused than ME. This interpretation is consistent with the balance of Robin and Reidenbach's article, wherein marketing ethics is linked to Kolhberg's (1984) stages of moral development as they might influence the larger society.

Another seminal contribution to marketing literature explores the CSR and marketing nexus (Maignan and Ferrell 2004). First, the article reviews most of the literature that seems to touch on marketing ethics in a CSR context, however remotely. Second, the authors observe that marketing ethics understandably focuses 'on two main groups of stakeholders: customers and channel members' (p. 5). This observation suggests that marketing CSR is part of a greater CSR, just as marketing ethics is one component of business ethics. Third, Maignan and Ferrell (2004), in specifying 11 likely propositions, develop the notion of stakeholder responsiveness as the common denominator of marketing ethics and CSR. Noting stakeholders as the immediate focus of CSR in marketing is entirely consistent with the definition of CSR we have already outlined above.

Perhaps the article that addresses the marketing ethics/CSR interface with the greatest sophistication is Vaaland et al. (2008), although it examines the marketing-related aspects of CSR research without making a direct connection to the theoretical marketing ethics literature. Herein 54 refereed journal articles about CSR in marketing, published between 1995 and 2005, are reviewed for the purpose of better establishing the domain of social responsibility in marketer actions. Ethical action taken within the organization - especially as affecting consumers - is found to be one of the three major themes of marketing-connected CSR research. The other two dimensions established are the societal and physical environment impacts of marketing decisions. These authors put forward a reconstituted definition of CSR in marketing that highlights 'the management of stakeholder concern for responsible and irresponsible acts' (ibid., p. 931). This description is also fairly consonant with the Murphy et al. (2013)-inspired definition of CSR in marketing that we offered above. That Vaaland and colleagues propose an upgraded definition of socially responsible marketing that utilizes 'responsibility' as one of its major specifications is a tautological discussion for another time.

Surprisingly, the best standing articulation of the connection between marketing ethics and CSR may exist not in a scholarly article but instead in the American Marketing Association's 'Statement of Ethics' (2008). Within that statement, promulgated by the largest marketing practitioner organization in the world, two general norms for professional practice are proffered - to 'never knowingly do harm' and to 'foster trust in the mar- 
keting system by avoiding deception'. Both norms are fundamental precepts of applied moral philosophy and have clear roots in general ethical theory. Significantly, there is the third, rather complex, norm, which asks marketing practitioners to embrace six values in carrying out their duties: honesty, responsibility, fairness, respect, transparency and citizenship. It is within this third norm - calling for adherence to certain fundamental business virtues - that the connection between marketing ethics and CSR is most evident. In the explication of these virtues, a series of express actions, which cannot be interpreted as anything other than a clarion call for social responsibility, is described as being essential to marketing ethics. Without question, the type of ethical marketing that is described in this code has a societal dimension that goes far beyond the law. Specifically, ethical marketers are encouraged to embrace (among various others) the following CSR-centered actions:

- Acknowledge the social obligation to stakeholders

- Consider environmental stewardship in our decision making

- Treat everyone, including our competitors, as we would wish to be treated

- Strive to protect the ecological environment

- Give back to the community through volunteerism and charitable donations.

To summarize the major points made so far: (a) marketing ethics often deals with decisions made by managers and whether those actions/ decisions conform to certain moral and professional standards; (b) professional ethics is not value neutral; the very fact that marketing ethics is regularly specified in company policy and by other entities suggests that it has a normative, aspirational dimension - we label this 'ethical marketing' in our discussions; (c) as market exchange is an inherently social process, marketing will necessarily have some societal effects for which the actors (i.e. marketing firms) are responsible; (d) these societal impacts are the essence of social responsibility in marketing. All the questions and issues surrounding such broader social effects are therefore an important part of both marketing ethics and social responsibility in all business organizations.

\section{THE SOCIAL CONTRACT WITH BUSINESS}

All of this begs the question: why do marketers have such connected ethical and social responsibilities? While this forum does not remotely 


\section{4 \\ Handbook of research on marketing and CSR}

allow a full explication of this issue, the roots of the answer lie in the fundamental social contract that exists between businesses and society.

Within a capitalist system, businesses play a major role in providing the goods and services that all communities require to flourish and grow. In exchange for investing capital, seeking innovation and bearing risk, the rewards of profit rightly accrue to participating business organizations. However, the license to operate as the provider of needed products and services comes from society. For example, according to the US Constitution (Article 1, Section 8), the federal government (representing society) reserves the right to regulate commerce in the public interest. Similar institutional constraints on business activity are active in almost all developed economies.

In this macro context, society is understandably concerned with social outcomes other than the profits to which business aspires. For instance, primary to this inquiry are questions such as: Are the goods required by the public being provided in sufficient quantity and at a fair price? Does distribution and promotion cost too much? Is business providing as much to the host community as it receives from it?

Along with having answers to these questions, society does not wish to bear undue costs from the side-effects of business endeavors (e.g. environmental pollution, exploitation of workers, predatory rent seeking). Minimally, this means that business in general, and marketers in particular, are expected to conform to the existing law. Proactively, the social contract would imply that Business (capital B) be evaluated on social dimensions such as job creation, whether investments have reasonable long-run sustainability, the absence of stakeholder exploitation and if companies pay their fair share of taxes to support the public infrastructure from which they benefit. Thus, the notion that financial outcomes for individual firms should be 'maximized' can be at odds with the principle of the-common good as perceived by society. We will return to the question of what constitutes the common good later in this chapter.

\section{WHAT CSR IN MARKETING IS NOT}

Given the high level of abstraction that is part of defining CSR - often involving slippery terms such as corporate responsiveness, social obligations and public expectations - it is useful to explore what CSR in marketing is not. Our most important observation here is that the original doctrine of CSR was never intended to be an instrumental strategy to fuel the competitive advantage of individual firms (Acquier et al. 2011). 
Howard Bowen (1953), the first detailed articulator of social responsibilities for business executives, saw the pressure for social and eleemosynary obligations as stemming from society - which plays the dual role of both client and supervisor. In particular, society seeks the achievement of economic goals in a manner consistent with public expectations. Bowen writes, 'those who own property have the duty of using and administering it, not exclusively for their own purpose, but in ways that will serve the needs of the whole society' (p. 53). In fact, Bowen argued that, since most organizations possess some degree of monopoly power, they could sacrifice some profit for social ends and still survive (Acquier et al. 2011). Unfortunately, many of today's discussions of CSR and its attendant 'management of stakeholders' articulate more limiting and self-serving positions such as:

- treating employees well in order to increase the likelihood of qualified labor working at your firm;

- satisfying customers because customer retention is cheaper than customer development;

- producing safe products because litigation is expensive;

- striving to avoid major damage to the ecological environment in order to forestall further regulations.

A related and particularly dangerous social trap is the willingness of some academics to let slide, without challenge, the increasing tendency of corporations to drop the 'S' from CSR and to refer only to 'corporate responsibility'. Presumably this is done because the dimensions that constitute 'consensus' societal expectations are difficult to pin down (Devinney 2009). The twisted logic behind this approach of ignoring the ' $S$ ' in CSR can go something like this:

(1) Corporations are people or, at minimum, very much like people.

(2) As with persons, while there might be desirable, voluntary obligations undertaken by corporations that improve society, the only corporate responsibility that unequivocally exists ( $\mathrm{CR}$ without the ' $\mathrm{S}$ ') is to obey the law.

(3) Corporate citizenship, while admitted in CR reports to be desirable, is at the discretion of business, and thus companies can 'pick and choose' from a menu of possibilities for any community building that they wish to undertake.

(4) The wisest firms select 'responsible' actions that enhance profitability and eschew socially desirable actions where marginal costs are perceived to exceed direct company benefits. 


\section{Handbook of research on marketing and CSR}

The great danger of this line of reasoning is that it implies that all social obligations are at the option of business rather than being demarcated and impelled by public and social mandate. Put another way, this instrumental view is a warmed-up version of Milton Friedman's (1970) argument against CSR: the business of business is to maximize profit, subject to the law, and only those voluntary community-enhancing actions that economically benefit the organization should be considered. Thus, in this vein, the hypothetical large oil company may generously support the performing arts (and use that charitable financing as a public relations tool). Meanwhile, behind the scenes, they might also financially underwrite those who try to cast doubt on 'global warming' since such realities threaten the future demand for oil; they may also minimize expenditures on expensive clean-ups that cannot be legally proven to be long-term environmental degradations.

We assert that the main reason that the logic chain of dropping the ' $\mathrm{S}$ ' from CSR is flawed is because business is basically an affiliated social institution that is charged with helping achieve economic and societal objectives. Business activities obviously extend beyond the parties to the immediate market exchange. For example, product packaging and obsolete products require public disposal; the demand for inexpensive toys, textiles and electronics creates pressures for off-shoring and sweat-shop labor; these secondary effects suppress local business expansion, eliminate jobs and reduce the tax base of higher-wage markets.

The social role of businesses should be evident to all. Most business executives admit a collective responsibility to provide jobs ('Business creates jobs, not the government' is the usual mantra). Indeed, the self-proclaimed role of business investors and corporations as 'job creators' and 'wealth generators' leads them to seek entitlements for tax breaks and other government subsidies (e.g. tax credits in exchange for the expansion of a corporate headquarters). If the actions of businesses in the normal discharge of their duties are so essential to the public's economic and, therefore, societal well-being, keeping the ' $\mathrm{S}$ ' in CSR seems logically and linguistically obvious. Of course, such social importance also underscores the critical role of government (as the public's representative) having the power to sometimes constrain business and marketer actions in order to promote the common good.

\section{VITALIZING CSR IN ETHICAL MARKETING PRACTICE}

Stipulating that external social pressures are rightly exerted on marketing managers to behave ethically, and that the public needs to keep a watch- 
ful eye on the societal impacts of their decisions, what might marketresponsible CSR look like? We offer four observations about CSR in marketing and its ethical impact. The dimensions we discuss have to do with proportionate duty, stakeholder orientation, distributive justice and stewardship. A similarity among these factors is that they each connect to the understanding of the elusive notion of the common good.

\section{Observation 1}

Following the principle of proportionality, Keith Davis (1960), an Arizona State University professor, proposed the 'iron law of social responsibility', which basically states that the social responsibility of business should be proportional to its power; the greater power an organization has, the greater the social responsibility it should exercise. Furthermore, if an organization does not use its power responsibly, its influence eventually will be reduced or constrained by society in some fashion (Davis et al. 1980). Thus, for instance, General Electric as one of the world's largest corporations has a far greater duty to be socially aware and responsive than a small start-up firm that has attracted its initial venture capital funding. (Of course, both companies must, at minimum, obey the law.) One upshot of this guideline is to remind us that ethical obligations are not uniform. In a manner, it reinforces notions of the previously discussed social contract in that organizations given great economic opportunity (for profit) owe society more than mere economic competence. The right to seek profit, which is accorded and supported by society, is balanced by an obligation to be accountable to society in a manner going beyond the de minimis requirements of the law. A discernible ethical imperative for corporations is to always consider the iron law of social responsibility when formulating and selecting marketing strategies. This would also apply when assessing whether a company's CSR duties have been fully executed.

\section{Observation 2}

The adoption of a stakeholder orientation is essential to the advancement and maintenance of ethical decision making in socially responsible organizations (Laczniak and Murphy 2006). The stakeholder concept embodies the idea that organizations operate with a responsibility that goes beyond fiduciary duties to owner-shareholders or even immediate customers. A failure to meaningfully embrace stakeholders and give them 'voice' within a firm's strategic conversations nudges companies toward the default position of shareholder wealth maximization, subject only 
to the constraints of law. In reality, most marketing organizations have now publicly adopted the language of stakeholder orientation; this is reflected in numerous statements made in annual and CSR reports and on company websites. However, in many cases, the actual implementation of stakeholder orientation has been a cost-benefit decision. In such situations, stakeholders are empowered in matters where proper stakeholder relations seem likely to improve profits (e.g. charitable donations to the community today may pave the way for developmental tax credits tomorrow). Under other scenarios, where stakeholder concern is quite costly (e.g. company-created 'brown fields' need to be restored from prior pollution), the firm will be less cooperative despite clear causal responsibility. We have argued elsewhere, and in some detail (Laczniak and Murphy 2012), that authentic stakeholder orientation must examine stakeholder claims from a macro-systems perspective instead of only from the standpoint of the firm in question. Furthermore, if the formulation of stakeholder oversight is motivated by only an instrumental, profit-centered criterion, this is not a genuine stakeholder orientation from society's viewpoint.

\section{Observation 3}

While marketers are responsible for their strategic intent as well as the method by which they execute their strategies, outcomes clearly matter. In this regard, a CSR perspective should require an examination of distributive justice. In a marketing context, distributive justice involves an analysis of whether the benefits and burdens of market exchange systems - the outcomes of market activity - are fairly allocated among stakeholders (Laczniak and Murphy 2008). For example, in the early 2000 s, the subprime mortgage market appeared be to creating multiple winners: loan originators had large profits; home buyers were receiving financing for houses they had not previously thought they could afford; and investors were offered innovative (seemingly risk-free) investment options that bundled such mortgages into high-yield, collateralized debt obligations. Of course, appearances were deceiving because in reality the risky market (built on the assumption that housing prices could never fall) crashed, leaving US taxpayers compelled to bail out reckless and irresponsible financial institutions. The point is that, from the standpoint of distributive justice, this was hardly a 'fair' outcome to the (stakeholder) members of the public. The profits of the market run-up had been 'privatized' by banks and their executives, but many trillions of dollars in losses were socialized across the public. Of course, the enduring challenge in establishing social justice is to be able to apportion what fair 
outcomes ought to be in particular situations. As generators and beneficiaries of wealth creation, business firms should look at defensible distributions from a multi-stakeholder perspective: employees (Living wages being paid?), customers (Fair value propositions being offered?), owners (Acceptable ROIs?), suppliers (Equitable conditions of profit sharing?), and the community (Just tax rates?). From a CSR in marketing standpoint, such assessments should be dominated by how existing market mechanisms in particular economic sectors affect the common good via just allocations of rewards.

\section{Observation 4}

Both the marketing companies and their managers that practice EM and CSR are likely to follow the stewardship principle, meaning that they take a long-term view toward the impacts of their decisions on multiple stakeholders. In contemporary parlance, the term 'sustainability' has both a broad (i.e. continuing to exist as a responsible business in the future) and narrow interpretation (i.e. environmental policies that are more benign to the natural world). We believe that the notion of stewardship captures the essence of sustainability while having a moral grounding in both theological and philosophical literatures. One company that is known for practicing the stewardship notion is Costco. Its co-founder and recently retired CEO, Jim Sinegal, stated that he is managing the business to be in operation for 50-60 years in the future. He has incurred the wrath of Wall Street analysts for taking this long view but he is adamant that the firm will not waiver from this approach. In the organization's values statement, taking care of members (i.e. customers) and employees while respecting suppliers all consciously come before rewarding shareholders. On the environmental dimension, retailers such as Costco, and even Wal-Mart, are forcing their suppliers to provide products that are less environmentally damaging:

'Consumers are holding the retailer, rather than the manufacturer,
increasingly accountable for over packaging,' states Mike Skrovanek,
MeadWestvaco's general manager for Natralock. 'Retailers like Costco can
use their clout to make the retail packaging changes consumers are now
demanding. Costco has been a very progressive partner willing to look at new
ideas, to make changes for a positive environmental performance.' (Addicted
to Costco! 2010)

This quote illustrates both an application of the stewardship principle as well as the principle of proportionality discussed in Observation 1. These four observations provide an architecture for both CSR and EM. 


\section{SOCIALLY RESPONSIBLE MARKETING AND THE COMMON GOOD}

The question of what constitutes the common good must now be addressed since it keeps cropping up in our various discussions of CSR and ethical marketing (Murphy and Sherry 2013). It is rightly said that different people (and different cultures) perceive what should comprise the 'good' quite differently. The thorny question is: who decides if the common good is being achieved and by what standard is that judged?

From the standpoint of communitarian ethics (Etzioni 1993), the common good consists of the sum total of social conditions that allow people as a community or as individuals to fully develop their human potential. The old US Army ad slogan comes to mind in this regard: 'Be all that you can be,' although such an achievement should be seen in a context that anchors individuals as part of a larger group - family, neighborhood, community, city/state, society and so on. The core idea is that common goods involve all those capabilities that enable human beings to fully participate in their individual and communal development (Sen 2009). Thus, in addition to basic freedoms - life, liberty and the pursuit of happiness, the critical essentials as seen from a US perspective-certain other collective capabilities are also necessary. Safety is a most obvious capability as citizens need to be protected from unfair interference from others. Such protections would involve institutional controls that would mitigate the damages that might stem from violence, environmental catastrophes or arbitrary detention by the more powerful. The protection of personal property from unfair seizure is yet another enshrined safety right. However, consistent with the United Nations Declaration of Universal Human Rights, other important capabilities also quite likely include access to education, basic healthcare and job opportunity. To be sure, people cannot pursue thęir dreams without at least a modicum of education; individuals cannot earn a living if they are sick and have no ability to seek medical attention; most people cannot flourish without access to employment even when they are willing and able to work.

The point is that all of these rights - safety, jobs, education and healthcare - should be part of the social discussion regarding what ought to be taken into account when establishing the common good. Economic products and services provided by business are a big part of the commongood equation but there is more to developing a flourishing society than that. When such 'macro' considerations are raised by social analysts, business executives often cringe; they wrongly perceive 'distributive justice' and the 'common good' as code words for socialism. In fact, marketing and marketing ethics remains fundamentally about allocation via markets. 
The vast majority of critiques by marketing ethicists and CSR analysts of some marketing practices are not radical but incremental (cf. Murphy et al. 2012). Markets are central for efficiently and effectively registering the preferences of consumers about their personal choices. Economic calculations are understood to function better through free market exchanges than alternative methods (e.g. bureaucratic planning). It is only when markets exploit consumers, damage society or when they fail to provide the basic capabilities needed to enhance the common good that public intervention is necessary to constrain or help reform market-based allocations. In this context, ME and CSR might be seen, somewhat minimally, as the undertakings of marketing organizations to provide a social contribution and to help markets work better even as such actions forestall further formal regulation of business.

\section{MEASURING AND TRACKING CSR FROM THE PERSPECTIVE OF MARKETING ETHICS}

Clarifying the interrelated nature of marketing ethics and CSR as complementary concepts with sometimes similar areas of focus also has pedagogical value to academics. However, its largest contribution lies in articulating these elements in a manner that allows academic researchers to more easily chart the existing gaps between the realities of marketing practice and the ethical aspirations that marketers should seek, and which society demands, from socially responsible corporate citizens. From a micro- or firm-level perspective, much of the effort to understand the CSR contributions of marketing would seem to involve tracking firm performance along the increasingly utilized 'triple bottom line' dimensions (Elkington 1998; Kaplan and Norton 1992). That is, ethical marketing in a socially responsible manner should contribute to the economic development of the firm's local/global community in a manner consistent with the common good. To demonstrate their value to society, ethical marketers should strive to provide a more complete record of the social benefits and burdens for which they may be responsible. In other words, the measure of a firm's social success, suggested to be fundamental by the aforementioned social contract, should be tracked with metrics that are more than financial; additionally, these measures should reflect the extent of a firm's full societal contribution to all stakeholders, including the general public. Academic marketing researchers need to construct, critique and improve such central metrics of marketing benefits. Among the factors that should be logged in a marketing audit of social and environmental activities would be the following: 
- The societal contribution of marketing organizations to long-run community welfare that goes beyond profits This might involve tracking jobs created, local partnerships with suppliers and distributors, new products launched, patents and innovations generated, charitable donations made, volunteer activities undertaken by employees, amounts of taxes paid and so on.

- An environmental audit that demonstrates sustainable and nonexploitative marketing operations This possibly includes commentary on recycling, environmentally friendly packaging, responsible water use, ecologically friendly operation and restorations and so on.

- A longitudinal record of who stakeholders are, how they are treated and in what manner they are given 'voice' regarding their key issues of concern Such information might record customer satisfaction, employee benefits, procedures concerning the treatment of suppliers, executive compensation as a (comparative) 'ratio of payouts to shareholder return', as well as full disclosures of all legal violations and political contributions.

From a macro perspective, ethical marketing in a socially responsible manner also requires a more systemic and societal analysis. At the most fundamental level, researchers need to chart whether various marketing sectors are meeting public expectations. In recent years, such macro analysis of marketing sectors has been sorely lacking (Wilkie and Moore 1999). In particular, data-driven judgments need to be made about how 'socially effective' specific sets of market exchanges in various economic sectors might be. Here are some general questions that macromarketing researchers need to answer for each important sector of a market-based economy: Is there reasonable service choice for buyers? Is the product/ service assortment safe? Do consumers have the necessary information to make rational choices? Do mechanisms to provide restorative justice exist when the market system fails the buyer or seller?

Thus, in today's dynamic, competitive environment, society increasingly wonders how the ethics of certain specific industrial segments might be judged in terms of their CSR. Are airlines being transparent when they unbundle various services such as bag-checking fees, early boarding, snacks and headphones but still advertise a base price? Are cable TV companies offering real choice when they force customers to buy many channels that they do not watch? Are health insurance companies that limit lifetime coverage to specific amounts being fair? Are banks that have been 'bailed out' but refuse to lower the mortgage payment rates of customers whose home values are under water being equitable? 
The questions posed above speak especially to the consumer as stakeholder. But each marketing sector can also be evaluated as to whether it makes its fair contribution to the betterment of society. This suggests formulating measures regarding the quality of life (QoL) as shaped by marketing (Kilbourne et al. 1997). The standard model of counting only financial returns (micro) and GDP (macro) seems to be in need of major amendment. Some social critics are advocating tracking gross national happiness rather than gross domestic product (Weiner 2008). Bhutan is one such country that began this practice in the early 2000s. The idea behind looking at 'happiness' is that economic expenditures alone do not provide a very good measure of social well-being. Sometimes, a greater GDP can mask social pathologies. For example, aggregate expenditures on maintaining prisons, treating victims of mental illness, manufacturing anti-personnel land mines and advertising cigarettes all get added to GDP in a 'positive' way, but such activities do not remotely appear to be an indicator of 'good' community health. As Robert F. Kennedy said in 1968 about GNP (GDP's predecessor measure), '[it] does not allow for the health of our children, the quality of their education or the joy of their play. It does not include the beauty of our poetry or the strength of our marriages ... it measures everything in short, except that which makes life worthwhile' (quoted in Koch 2012).

\section{HYPER NORMS AND CSR}

Most of the above macro issues speak to the primary effects of market exchange. Another set of larger considerations flows from the secondary and tertiary effects caused by marketing actions. Ethical marketing, as discussed above, requires that marketers be responsible for whatever they intend as a means and outcome of their actions. At minimum, marketers should internalize the cost of fixing any foreseeable, negative outcomes of their decisions. The $2010 \mathrm{BP}$ oil spill is a case in point. Certainly it was not the intention of BP to pollute the Gulf of Mexico and cripple the economy of three US states - yet this was an unexpected consequence of a market process. In hindsight, evidence indicated that this possible outcome should have been foreseen, especially as BP chose to compromise on various safety mechanisms for its Deepwater Horizon oil drilling platform. Partly resulting from the arrangements made between BP, Transocean (the drilling platform provider) and Halliburton (the safety protocol formulator), a catastrophic event ensued. The final rectification cost to $\mathrm{BP}$ will range from $\$ 20$ to $\$ 30$ billion. However, the general lesson here is that the moral duty of socially responsible marketers goes beyond the ramifications of the 
immediate exchange and extends marketing responsibility into the heart of what is ethically owed to society.

Finally, consideration must be given to making transparent the guiding norms under which all marketing firms will operate. As with previous macro concepts, skeptics doubt the ability to specify global norms - or hyper norms - that might be agreed upon as universal by a diverse and culturally divergent world community. But the domain of interest here is not the entire world populus but only the association of global business firms operating in it. While these companies represent a huge economic resource with vast differences among them, there are presently arrangements such as contract law, international accounting standards and corporate charter requirements to which they all already subscribe. Business corporations hate uncertainty, and knowing the universal ethical 'rules of the game' helps alleviate that. What exactly is the nature of such universal norms? 'Hyper norms' are enduring ethical rules or principles that are consistently reiterated across different times, cultures, histories and civilizations (Donaldson and Dunfee 1994). Thus, is it so difficult to imagine that global corporations would not wish to acknowledge some basic hyper norms? The existence of global norms reduces business uncertainty and provides marketing firms with guidelines that mitigate costly social mistakes.

Building on Donaldson and Dunfee (1994), the main implication for marketing can be clearly seen through the concept of integrated social contracts theory or ISCT (Dunfee et al. 1999). ISCT posits that cultural differences can be accommodated in a 'moral free space' that recognizes divergent ethical perceptions across cultures so long as global hyper norms are both specified and honored. For example, the relatively lavish gift-giving of Japan, the recognition of reciprocal relationships in China and the necessity of small facilitating payments in India often can be finessed as long as larger global hyper norms are not transgressed. In a subjective, qualitative exercise to uncover and better understand such hyper norms, one of the authors was involved in a project that scrutinized seven global codes of ethical business conduct (Laczniak and Kennedy 2011). According to that analysis, the three common global hyper norms that emerged were:

- a comprehensive stakeholder orientation that was motivated by the centrality of human dignity;

- a commitment to sustainable business practices that includes both protection of the physical environment as well as a dedicated commitment to ongoing local operations;

- an authentic compliance that involves adherence to the letter and spirit of the law, including a demonstrated advocacy against bribery and corruption in business practice. 
Each of these hyper norms affirms the fundamental observations offered earlier in the chapter.

The point is that such global hyper norms could be the sacrosanct ethical values that MNCs should never transgress anywhere they operate. These hyper norms might also be seen as a surrogate measure for whether the 'common good' expectations for marketing operations are being delivered to the marketing firm's host communities.

\section{CONCLUSION}

In summary, ethical marketing practice is a central component of the CSR of marketing. In turn, CSR is a major touch point for establishing whether the collective actions of a global and wide-ranging business system adhere to the basic social contract that undergirds the marketing operations of all business firms. If nothing else, those working to understand and improve marketing ethics should realize that they are often addressing questions of CSR because marketing actions are typically integrated with the common good of the broader society; those who labor in CSR research, when looking at issues of market exchange, should recognize that the marking ethics literature may hold major insights for their analysis because the aggregate propriety of individual managerial actions will affect the firm's social performance. In light of our discussion, we predict that, as the twenty-first-century business climate unfolds, marketing ethics and CSR in marketing will be broadly perceived as synonymous concepts.

\section{REFERENCES}

Acquier, A., Gond, J.-P. and Pasquero, J. (2011), 'Rediscovering Howard Bowen's legacy: the unachieved agenda and continuing relevance of social responsibilities of the businessman', Business \& Society, 50(4), 580-606.

Addicted to Costco! (2010), 'Costco updating packaging to an eco-friendly style', accessed at http://addictedtocostco.com/2010/06/24/costco-updating-packaging-to-eco friendly-style/.

American Marketing Association (2008), 'Statement of ethics', accessed at http://www.marketingpower.com/AboutAMA/Pages/Statement $\% 20$ of\%20Ethics.aspx.

Bowen, H.R. (1953), Social Responsibilities of the Businessman, New York: Harper.

Carroll, A.B. (1979), 'A three-dimensional conceptual model of corporate performance', Academy of Management Review, 4(4), 497-505.

Carroll, A.B. (1999), 'Corporate social responsibility: evolution of a definitional construct', Business \& Society, 38(3), 268-95.

Dahlsrud, A. (2008), 'How corporate social responsibility is defined: an analysis of 37 definitions', Corporate Social Responsibility and Environmental Management, 15(1), 1-13.

Davis, K. (1960), 'Can business afford to ignore social responsibilities?', California Management Review, 2(3), 70-77. 
Davis, K., Frederick, W.C. and Blomstrom, R.L. (1980), Business and Society, 2nd edn, New York: McGraw-Hill.

Devinney, T.M. (2009), 'Is the socially responsible corporation a myth? The good, the bad, and the ugly of corporate social responsibility', The Academy of Management Perspectives, 23(2), 44.

Donaldson, T. and Dunfee, T.W. (1994), 'Toward a unified conception of business ethics: integrative social contracts theory', The Academy of Management Review, 19(2), 252-84.

Dunfee, T.W., Smith, N.C. and Ross Jr, W.T. (1999), 'Social contracts and marketing ethics', Journal of Marketing, 63(3), 14-32.

Elkington, J. (1998), Cannibals with Forks: Triple Bottom Line of $21^{\text {st }}$ Century Business, Vancouver: New Society Publishers.

Etzioni, A. (1993), The Spirit of Community: Rights, Responsibilities and the Communitarian Agenda, New York: Crown.

Freeman, R.E. (1984), Strategic Management: A Stakeholder Approach, Boston, MA: Pitman.

Friedman, M. (1970), 'The social responsibility of business is to increase profit. A doctrine by Milton Friedman', New York Times Magazine (13 September) 1, 32-3, 122, 124, 126.

Hunt, S.D. and Vitell, S. (1986), 'A general theory of marketing ethics', Journal of Macromarketing, 6 (Spring), 5-15.

Kaplan, R.S. and Norton, D.P. (1992), 'The Balanced Scorecard - measures that drive performance', Harvard Business Review, 70(1), 71-9.

Kilbourne, W.E., McDonagh, P. and Prothero, A. (1997), 'Sustainable consumption and the quality of life: macromarketing challenge to the dominant social paradigm', Journal of Macromarketing, 17(1), 4-24.

Koch, W. (2012), 'If money doesn't buy happiness ... what does?', USA Today (2 August), $1-2 \mathrm{~A}$.

Kohlberg, L. (1984), The Psychology of Moral Development: The Nature and Validity of Moral Stages, San Francisco: Harper \& Row.

Laczniak, G.R. and Kennedy, A.M. (2011), 'Hyper norms: searching for a global code of conduct', Journal of Macromarketing, 31(3), 245-56.

Laczniak G.R. and Murphy, P.E. (1993), Ethical Marketing Decisions, Boston, MA: Allyn \& Bacon.

Laczniak, G.R. and Murphy, P.E. (2006), 'Normative perspectives for ethical and socially responsible marketing', Journal of Macromarketing, 26(2), 154-77.

Laczniak, G.R. and Murphy, P.E. (2008), 'Distributive justice: pressing questions, emerging directions, and the promise of Rawlsian analysis', Journal of Macromarketing, 28(1), 5-11.

Laczniak, G.R. and Murphy, P.E. (2012), 'Stakeholder theory and marketing: moving from a firm-centric to a societal perspective', Journal of Public Policy \& Marketing, 31(2), 284-92.

Maignan, I. and Ferrell, O. (2004), 'Corporate social responsibility and marketing: an integrative framework', Journal of the Academy of Marketing Science, 32(1), 3-19.

Matten, D. and Moon, J. (2008), "Implicit" and "explicit" CSR: a conceptual framework for a comparative understanding of corporate social responsibility', Academy of Management Review, 33(2), 404-24.

Murphy, P.E. and Sherry, J.F. (eds) (2013), Marketing and the Common Good: Essays from Notre Dame on Societal Impact, Oxford: Routledge.

Murphy, P.E., Laczniak, G.R., Bowie, N.E. and Klein, T.A. (2005), Ethical Marketing, Upper Saddle River, NJ: Pearson Prentice Hall.

Murphy, P.E., Laczniak, G.R. and Prothero, A. (2012), Ethics in Marketing: International Cases and Perspectives, Oxford: Routledge.

Murphy, P.E., Oberseder, M. and Laczniak, G.R. (2013), 'Corporate societal responsibility in marketing: normatively broadening the concept', AMS Review, 3(2), 86-102.

Nill, Alexander and Schibrowski, J.A. (2009), 'Research on marketing ethics: a systematic review of the literature', Journal of Macromarketing, 27(3), 256-73.

Robin, D.P. and Reidenbach, R.E. (1987), 'Social responsibility, ethics, and marketing strategy: closing the gap between concept and application', Journal of Marketing, 51(1), 44-58. 
Schlegelmilch, B.B. and Oberseder, M. (2010), 'Half a century of marketing ethics: shifting perspectives and emerging trends', Journal of Business Ethics, 93(1), 1-19.

Sen, A. (2009), The Idea of Justice, Cambridge, MA: Belknap Harvard Press.

Vaaland, T.I., Heide, M. and Gronhaug, K. (2008), 'Corporate social responsibility: investigating theory and research in the marketing context', European Journal of Marketing, 42(9/10), 927.

Weiner, E. (2008), The Geography of Bliss: One Grump's Search for the Happiest Places in the World, New York: Hachette Book Group.

Wilkie, W.L. and Moore, E.S. (1999), 'Marketing's contributions to society', Journal of Marketing, 63(Special Issue), 198-218. 